\title{
Mapping recent developments in Old Testament theology
}

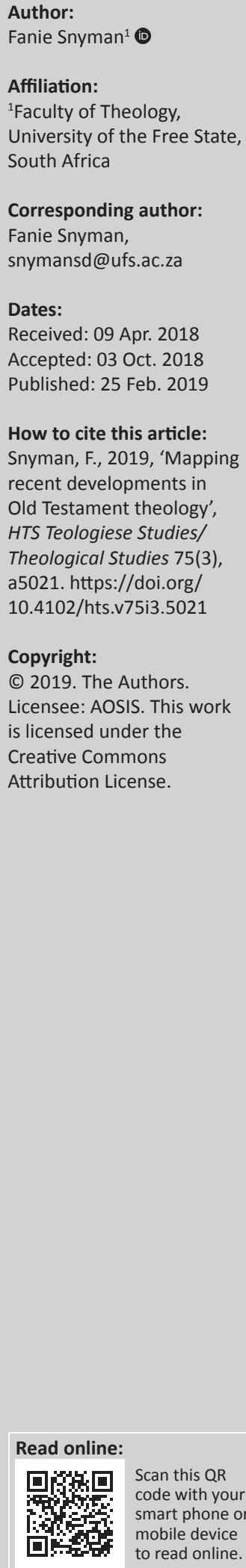

This article provides the readers with an overview of the history of the study of the Old Testament, highlighting major turning points especially during the 20th and 21st centuries. It is argued that the approaches of Eichrodt, Von Rad, Childs and Brueggemann mark the major innovative developments in Old Testament theology during the 20th and 21st centuries. The article concludes with a number of conclusions based on the overview of developments in the field. The postmodern turn represented in especially the Old Testament theologies of Brueggemann and Gerstenberger is pointed out together with other trends that can be detected from recent developments in the field.

\section{Introduction}

For many years Old Testament theology has been a problematic branch in Old Testament studies. It has been dubbed a 'non-existent beast' (Whybray 1978) and more recently Hagelia (2012:xi) made the following remark:

The study of the Old Testament has been under heavy pressure from different angles for decades and it is fair to say that there has been no real consensus during the last half century about how to write an Old Testament Theology. (pp. 168-180)

Yet, there is a never-ending flow of Old Testament theologies still being published. In the recent past, one may mention the Old Testament theologies of Gerstenberger (2002), Brueggemann (1997), Routledge (2008), Fischer (2012), Waltke (2007), Koorevaar and Paul (2013), Rendtorff (2005) and Jeremias (2015).

There is a general agreement that Old Testament theology is about God. Brueggemann (1997:117) states it quite clearly: 'The primal subject of an Old Testament Theology is of course God'. Rendtorff (2005:1) says: 'The Old Testament is a theological book'. In the very first sentence of his Old Testament theology, Fischer (2012) states:

In der ganzen Bibel gibt es kein umfassenderes und bedeutenderes Thema als ihr Reden von Gott. Das gilt bereits für das Alte Testament, in dem der Name Gottes, Jhwh, über 6800mal und Formen von 'Gott' weitere tausend Male genannt werden. (p. 13)

In the first sentence in his presentation of the theology of the Old Testament, Jeremias $(2015: 1)$ says: 'Eine Theologie des Alten Testaments (AT) zielt darauf ... die zentrale Gottesaussagen des Alten Testaments zu erheben'.

How to present a theology of the Old Testament is a quite different, difficult and complex matter. Jeremias (2015:2) gave an apt summary of the main reasons as to why it is such a difficult task. Firstly, the Old Testament presents the researcher with a collection of writings comprising a rich variety of literary genres. Secondly, the Old Testament came into being over a period of roughly 800 years. The kind of literature one finds in the Old Testament and the tremendous timespan over which the Old Testament originated are the main reasons why producing an Old Testament theology is such a complicated venture. Gerstenberger (2002:1) echoes the same point of view when he states: 'the Old Testament ... is a conglomerate of experiences of faith from very different historical and social situations'. To add to this, the historical distance between current readers of the Old Testament and the text of the Old Testament is also a matter to take into consideration, combined with a 2000-year-old tradition of interpreting the Old Testament. Consequently, the publication of books on the subject of Old Testament theology portrays a rich variety of approaches and methods. On the one hand, existing approaches are applied in new ways and, on the other hand, new ways of presenting a theology of the Old Testament are also published. To come to terms with the latest publications on Old Testament theology, an overview of the history of the

Note: The collection entitled 'Eben Scheffler Festschrift', sub-edited by Jurie H. le Roux (University of Pretoria) and Christo Lombaard (University of South Africa). 
subject is needed in order to detect existing approaches applied anew, while it is also necessary to have a grasp on the past to identify innovative ways in presenting an Old Testament theology.

Numerous and valuable books have been published on the history of the subject of Old Testament theology (Barr 1999; Denton 1963; Hasel 1991; Hayes \& Prussner 1985; Hogenhaven 1988; Reventlow 1985) and almost all presentations of Old Testament theology start off with an overview of the history of the discipline (cf. Anderson 1999:16-36; Brueggemann 1997:1-116; House 1998:11-57; Jeremias 2015:3-5; Koorevaar \& Paul 2013:21-50; Preuss 1995:1-126; Routledge 2008:27-71). This article first provides a fresh view of the history of the subject and then highlights some of the latest developments in the field of Old Testament theology, focusing mainly on developments in Europe, the US and the United Kingdom. New developments can only be identified in view of what has been done in the past. To produce an Old Testament theology is by its very nature a reductionistic endeavour. To provide an overview of the developments in the field of Old Testament theology covering a period of more than two centuries will then be even more reductionistic in nature. Not all literature or even books on the theology of the Old Testament could have been consulted (cf. Dumbrell 2002; Goldingay 2003; Merrill 2006; Perdue 1994, 2005). Waltke (2007:68) remarks in this regard: 'The discipline of Old Testament theology is so vibrantly multicolored that one cannot do justice to the field'.

\section{A brief overview of the history of Old Testament theology}

It is not evident at what time one may start with an overview of the history of the theology of the Old Testament. During the early years of the Christian church, there was little interest in the Old Testament. It was only during the time of the Reformation during the 16th century that attention was paid to the Old Testament owing to the 'sola scriptura' slogan of the Reformation. The interest in the study of the Bible in general and the Old Testament in particular did however not mean that theologies of the Old Testament were all of a sudden published. Luther's interest in the Old Testament lies mainly in his hermeneutical approach to the Old Testament presented in his classic formulation 'ob sie Christum treyben odder nit' (Frör 1968:118). Freely translated it can be rendered as 'whether the text reveals Christ or not'. This resulted in a Christological interpretation of the Old Testament.

\section{The 17th century - A dogmatistic approach to the Old Testament}

It was only during the 17 th century that one came across book titles with the term 'Biblical Theology'. The book by Wolfgang Jacob Christmann titled Teutsche Biblische Theologie is the first known book containing the concept of Biblical Theology in its title; however, this book sadly enough got lost so that no copy of this book exists (Hasel 1991:11).
The method employed during this time was fairly simple. A dogma from the church was taken as point of departure and then texts from the Bible that seem to be in support of church dogma were added to substantiate the church dogma (the so-called 'dicta probantia'). To put it in a nutshell: the church dominated dogmatic theology (Routledge 2008:28). The study of the Old Testament (or the New Testament) was not considered as a separate branch within the field of theology. The Old and New Testaments were rather seen as merely a source for supporting an already existing church dogma. Theology and the doctrine of the church were the same with no distinction between the different subjects within the field of theology we are accustomed to today and with the church actually dominating theology.

The God of the Old Testament was therefore portrayed as the dogmatic God, the God as portrayed by the doctrines of the church.

\section{The 18th century - The rise of a Biblical Theology}

The 18th century can be seen as the dawn of the age of reason or rationalism and became known as the 'Aufklärung' in German or Enlightment in English. It was the times of Rene Descartes with his well-known dictum cogito, ergo sum and Immanuel Kant, another most influential philosopher of the time, urged people to make use of their reason: 'Have courage to use your reason - that is the motto of the enlightment!' (Hayes \& Prussner 1985:53). Old Testament scholars such as J.G. Eichhorn and J.S. Semler emphasised the importance of a historical approach to the Old Testament and in this sense a beginning has been made to move away from the dogmatistic approach to the Old Testament.

An important event that may even be viewed as the birth of the theology of Old Testament happened on 30 March 1787 when J.P. Gabler (1753-1826) delivered his inaugural lecture as professor at the University of Altdorff. In this inaugural address 'Oratio de iusto discreme theologiae bibliae et dogmaticae, regundisque recte utriusque finibus' translated as 'On the proper distinction between Biblical and Dogmatic Theology and the specific objectives of each', he distinguished between a biblical and dogmatic theology. 'There is on the one hand, a truly biblical theology, of historical origin, conveying what the holy writers felt about divine matters; on the other hand, there is a dogmatic theology of didactic origin, teaching what each theologian philosophises rationally about divine things in accordance to his or her ability, time, age, place, sect or school and other similar things' (Brueggemann 1997:13; Hasel 1991:16; Jeremias 2015:11; Routledge 2008:30-31; Sandys-Wunch \& Eldredge 1980:133-158; Waltke 2007:30). Biblical theology is thus defined primarily as a historical discipline, while dogmatics or systematic theology is seen as a systematic approach to the Bible.

The end of the 18th century saw the publication of the first book titled Theologie des Alten Testaments authored by G.L. Bauer from Leipzig in Germany. The 18th century witnessed 
the important development of Old Testament theology into an independent subject separate from dogmatics. However, the influence of a dogmatic approach was still strongly present.

God is the God who revealed himself in history to different authors and the result of that is reflected in the Old Testament.

\section{The 19th century - The rise of a religion- historical approach to the Old Testament}

The effect of the German philosopher Hegel (1770-1831) had a defining impact on the study of the Old Testament. Hegel's philosophy can be (oversimplified) described as following a dialectic logic: there is a constant move from one thought (thesis) to its opposite (antithesis) to a combination of the thoughts (synthesis). Hegel applied his philosophy also to religion: religion was originally nothing else but a nature religion where nature was worshipped (thesis). Then God was worshipped independently from nature (antithesis) and eventually nature and God were unified in Jesus Christ (synthesis). Brueggemann (1997:11) termed this period as the time of evolutionary developmentalism.

Applied to the study of the Old Testament, this new intellectual climate gave rise to a religion-historical approach to the Old Testament. It is not the theology of the Old Testament that should be studied but rather the development(s) of religion as reflected in the Old Testament from Hebraism to Judaism and eventually to Christianity. The object of study should be the religion of Israel as it manifested itself in the course of history. Important names associated with this approach are William Wrede (1859-1906), Herman Gunkel (1862-1932), Hugo Gressmann (1877-1927) and Sigmund Mowinckel (1884-1965). The religion-historical approach reached its high point with the publication of Wellhausen's Geschichte Israels in 1878 that was later translated into English titled Prolegomena to the History of Israel. It has to be acknowledged that the religion practiced by Israel and Judah does have a history. In the Abrahamic narrative in Genesis 12-26 for instance, no mention is made of priests and the duties they perform at sanctuaries such as the temple of Solomon in later times. Abraham brought his sacrifices without the interference of a priestly office. Another example: there is a gradual movement to be detected where other gods are acknowledged but only YHWH may be worshipped (Ex 20:1-5) to a full blown monotheism where the God of Israel/ Judah is seen as indeed the one and only God (cf. Is 40-55).

To Dentan (1963:61), interest in the history of religion approach declined because of the general loss of faith in evolutionary naturalism, a mistrust in the mid-19th-century conviction that historical truth can be attained by pure scientific objectivity and the trend of continental theology going back to the Reformation.

A century later, the German Old Testament scholar Rainer Albertz (1992) sparked a renewed interest in a religionhistorical approach to the Old Testament over against a theological approach with his influential book Religionsgeschichte Israels in alttestamentlicher Zeit. For a while, there was a heated debate, which resulted in the point of view that we should not think in terms of an either/or approach but rather view the two respective fields of study as legitimate ways of studying the Old Testament. The remark by Jeremias (2015) is an apt summary of the controversy:

Vielmehr hat die Diskussion seiner (Albertz's) These gezeigt, dass nach dem Urteil der Mehrheit die 'RG Israel' und die 'Theologie des AT' als zwei Weisen, die zentralen Gedanken des AT zusammenfassen, eingeschätzt werden, die allerdings eine sehr unterschiedliche Intention haben. (p. 11)

God is the God worshipped in a variety of religious practices in the course of time.

\section{The 20th century - The rise of theological approaches to the Old Testament}

The study of Old Testament theology in the 20th century actually started at the end of World War I (1914-1918). In the decade following the end of the World War I, there was a growing conviction that more attention should be paid to a more theological approach to the Old Testament because the dominant religion-historical approach does not provide the answers to the questions posed in the aftermath of World War I. In 1921, Rudolf Kittel read a paper to a group of Old Testament scholars wherein he argued the necessity of paying attention to the enduring worth of the Old Testament. Consequently, in 1922, Eduard König published the first book in the 20th century titled Theologie des Alten Testaments.

The 20th century can be described as the golden era of Old Testament theology. Jeremias (2015:3) even regards the period following World War I as the real birth of Old Testament theology. Three major movements can be discerned during this period: the approach initiated by Walther Eichrodt, the approach developed by Gerhard von Rad and the approach Brevard Childs would become known for.

\section{Eichrodt}

Eichrodt published his theology of the Old Testament between 1930 and 1933. He structured his presentation in three themes: God and the People, God and the World and thirdly, God and man. He did that by stating that his aim is 'to plot our course as best as we can along the lines of the Old Testament's own dialectic' (Eichrodt 1975:33), thereby clearly distancing himself from a dogmatic approach to the Old Testament that followed the typical God-man-salvation scheme from systematic theology. The theological concept around which Eichrodt structured his theology of the Old Testament is the concept of covenant. It is the concept of the covenant as the 'definite expression to the binding of the people to God' that provides unity to the Old Testament as its central concept 'even where the word berit has disappeared altogether' (Eichrodt 1975:36). The importance of this approach can hardly be overstated in the sense that for the first time a theme or topic or centre was postulated as coming from the Old Testament itself and not from dogmatics. 
Eichrodt's approach was a decisive one in the history of Old Testament theology. Many other presentations of an Old Testament theology were published following the method Eichrodt employed. The approach of Eichrodt sparked a multitude of other presentations of the theology of the Old Testament, each positing a new centre of the Old Testament. A few well-known so-called centre-approaches are the holiness of God (Sellin), communion with God (Vriezen), the kingdom of God (Klein), promise (Kaiser), God's rulership and communion (Fohrer). More recent approaches still following a centre approach include the books of Preuss $(1991,1995)$ proposing YHWH's historical activity of electing Israel for communion with this world and the obedient activity required of this people and the nations (Preuss 1995:25), Routledge (2008) viewing the Old Testament as 'revelation of the truth about the nature and being of the living God and about its dealings with his people and the world' (p. 72) and Waltke (2007) who organised his view on the theology of the Old Testament around the concept of 'gift'. Mentioning only these few examples does not nearly exhaust the full amount of books applying this approach in presenting an Old Testament theology. The many centres posed suggested that posing one centre failed to encompass the richness of the Old Testament in its testimony about God and that therefore there is perhaps no single centre of the Old Testament except that it may be said that God is the centre of the Old Testament.

God is the God of whatever centre was posed upon the Old Testament.

\section{Von Rad}

According to von Rad, the interest a theologian has in the Old Testament is all about what Israel says about YHWH. Israel's utterances about God are, however, not found in dogmatic statements that can be easily looked up in the Old Testament. Israel's faith is grounded in a theology of history. Theology is presented as history, or to put it differently, theological truths are illustrated in a narrative. It is this very close relationship between theology and history that coined one of von Rad's famous statements: '... retelling remains the most legitimate form of theological discourse in the Old Testament' (Von Rad 1975:121). Events that happened were brought in relationship with YHWH. So, confessional summaries of salvation history were formulated primarily in a cultic context (Dt 26:5-9). These confessional statements were the nucleus from which traditions grew to eventually form the Hexateuch.

It is at once clear that this method differed completely from the centre-approaches that originated with the pioneering work of Eichrodt. For von Rad, God is the God of the tradition history where he revealed himself in the great narratives of his people. Therefore, the question to be answered for a theologian is the question of what Israel confessed about YHWH.

\section{Childs}

The third major methodological renewal can be attributed to the approach of the American Old Testament scholar, Brevard Childs. Childs himself saw his approach that came to be known as a canonical approach to the Old Testament as 'a fresh approach to the discipline' (Childs 1985:6). According to Childs, the canonical approach asserts 'that the object of theological reflection is the canonical writing of the Old Testament, that is, the Hebrew scriptures that are the received traditions of Israel' and not the events or experiences behind the text' (Childs 1985:6). The term 'canon' is important in the approach of Childs. Canonisation is seen as the final stage of a long process by which material was shaped theologically over a period of time 'to render it accessible to future generations of believers'. Because of the fact that an Old Testament theology is called as an Old Testament theology, it is a recognition that the Old Testament is part of Christian theology together with the New Testament. A few years after the publication of his Old Testament theology, Childs put this point of view in practice by publishing a book covering both the Old and New testaments titled Biblical Theology of the Old and New Testament (Childs 1992).

The task of Old Testament theology then is 'to hear its own theological testimony to the God of Israel whom the church confesses to worship' (Childs 1985:9). The God portrayed in the canonical approach of Childs is the God who revealed himself primarily through the Torah to his people through various agents so that they may respond with an obedient life.

It is interesting to note that the three major methodological innovations in Old Testament theology are in each case separated by more or less a period of 25 years. Twenty-five years after Eichrodt's theology, von Rad published the first volume of his Old Testament theology and 25 years later in 1985 Childs published his Old Testament theology.

\section{The 21st century - Diversity becomes the name of the game}

Perhaps, the clearest indication of a new approach to Old Testament theology is the acknowledgement of diversity or plurality in the Old Testament and in Old Testament theology. Two scholars who vividly demonstrated the aspect of diversity within the Old Testament are Brueggemann (1997) and Gerstenberger (2002). The publication of Old Testament theology books also shows that there is an almost bewildering plurality of approaches followed over against the three major approaches that characterised the 20th century Old Testament scholarship in the field of Old Testament theology.

\section{Brueggemann}

Brueggemann's (1997) theology of the Old Testament signifies a major milestone introducing a fresh approach to present a theology of the Old Testament. In fact, where Hagelia (2012:172) is still hesitant in his estimation of the importance of Brueggemann's theology, I regard his work as a landmark 
initiating the next major move in Old Testament theology after the pioneering work of Eichrodt, Von Rad and Childs in the 20th century. Old Testament theology in the 21st century was introduced not in 2001 but by Brueggemann's theology published in 1997. The innovative work of Brueggemann lies in his postmodern way of thinking and in the methodology he used in producing his theology of the Old Testament.

Brueggemann organises his rendition of Old Testament theology by means of the metaphor of a lawsuit trial. Presenting a theology of the Old Testament by way of a metaphor is a first and an indication of the innovative way in dealing with the Old Testament one may expect when reading his book. Fundamental to the court metaphor is the concept of testimony. In a court case, nobody has access to the actual events that happened. Brueggemann (1997:119) says in this regard: '... the largest rubric under which we can consider Israel's speech about God is that of testimony'. Testimony as a concept is at home in a court of law. A court can only rely on the testimonies of the witnesses to form a picture of the events reported or to put it in Brueggemann's (1997) words: 'It is on the basis of testimony that the court reaches what is

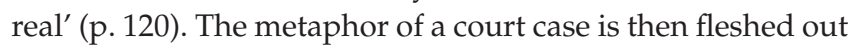
in exploring four different kinds of testimonies offered in the Old Testament: the core testimony, a counter testimony, an unsolicited testimony and an embodied testimony.

The core testimony consists of Israel's utterances about God in verbs describing especially God's actions in history (Brueggemann 1997:145). The counter testimony resembles the practice of cross-examination in court cases and according to Brueggemann (1997:317), it is remarkable that this crossexamination takes place within the Old Testament itself. Israel's 'lived experiences' do not always cohere with the core testimony, hence the counter testimony presented in questioning the hiddenness, ambiguity and negativity in YHWH (Brueggemann 1997:318). Unsolicited testimony refers to the event where a witness in a court case may present extra, superfluous testimony often even against the advice of the attorney. This unsolicited testimony of Israel is then dealt with as YHWH's partners under four headings: Israel, individual human persons, the nations and creation (Brueggemann 1997:411). Brueggemann named the fourth kind of testimony as the embodied testimony. If it is true that YHWH enters into a relationship of partnership as was explained in the third kind of testimony, exactly how does God and his partners make contact? Brueggemann wants to pay attention 'to the practices that give the testimony concrete embodiment' (Brueggemann 1997:568).

What makes Brueggemann's theology of the Old Testament theology postmodern? In contemplating the contemporary situation, Brueggemann (1997:61) explicitly addressed 'the postmodern interpretative situation' where he referred inter alia to the pluralistic context within which interpreters find themselves. His views on the role of rhetoric, intertextuality, his insistence on the polyvalence of the Old Testament, his critical comments on historical criticism and its positivistic modernist roots are all indicative of postmodern thought and influences (Brueggemann 1997:64-89). Hagelia (2012:80) pointed out how postmodernism has a profound scepticism towards any kind of metanarrative and how Brueggemann (1997:558) is uneasy with using the term metanarrative with reference to Old Testament theology. The current pluralistic situation suggests a contextual shift from hegemonic interpretations like that of Eichrodt and von Rad towards a pluralistic, interpretative context (Brueggemann 1997:710). Hagelia (2012:133) remarked that Brueggemann's theology has left a deep impact on the study of the Old Testament and that it will be referred to and discussed for years to come.

\section{Gerstenberger}

Another Old Testament scholar whose Old Testament theology can be seen as one written from a postmodern way of thinking is Erhard Gerstenberger. The title of his book is an indication of a different approach one might expect by making use of the plural form - theologies - followed by 'in' (and not 'of') the Old Testament. The title says that there is not a single theology to be detected in the Old Testament; rather, one should be sensitive to different theologies within the Old Testament. As is the case with Brueggemann, the emphasis is on diversity rather than unity as was the case in the centred approaches introduced by Eichrodt. In fact, Gerstenberger (2002:1) distances himself from the centred approaches by stating: 'The Old Testament, a collection of many testimonies of faith from around a thousand years of the history of ancient Israel, has no unitary theology, nor can it'.

Methodologically speaking, Gerstenberger's approach can be described as a blend of a social scientific approach, social anthropology, history and history of religion to end up with various pictures drawn in the course of history. Even when glancing through the headings of the different chapters in his book, it becomes clear that Gerstenberger wants to show that God is viewed differently by people at different historical and social stages. So, for instance, he treats historical and social developments from pre-Israel to Israelite family and clan society through village community, tribal community, monarchic era and the exilic period (Hagelia 2012:136). Each period paints a different picture of God and hence he came to the conclusion that we should rather speak of theologies in the Old Testament instead of a theology of the Old Testament.

An important aspect not to be overlooked is the very first sentence of the book where Gerstenberger states that this book is based on a series of lectures he presented in Brazil and Germany. The current historical context is therefore also important when one writes an Old Testament theology. He emphatically stated that 'we must insist that any theological approach ... is subject to its own limited, concrete, contextual conditions and therefore cannot be absolutized' (Gerstenberger 2002:5). As we as theologians approach the Old Testament, we do not do so unbiased and detached; in fact, we cannot separate ourselves from ideas and convictions that we bring to the texts we read. We are subjects engaging 
with a text and therefore objective theology is simply not possible. This aspect is reiterated several times in the book and in this way Gerstenberger implicitly signals that he has written a book with an inherent and basic postmodern aspect (Hagelia 2012:136). His view of the Old Testament as a dialogue partner (Gerstenberger 2002:17) is also indicative of a typical postmodern relativism critical of any authoritarian way of thinking.

\section{Some other recent approaches}

\section{Rendtorff}

Rendtorff's book, The Canonical Hebrew Bible - A Theology of the Old Testament, can be seen as the culmination of his version of a canonical approach to the Old Testament. Methodologically, he draws on two dominant approaches from the 20th century. On the one hand, Rendtorff sees himself following in the steps of von Rad but on the other hand he simultaneously developed von Rad's approach 'a step further' by 'making the texts themselves, in their present "canonical" shape, the point of departure for the account' (Rendtorff 2005:1). Although diachronic aspects of the text are not ignored, 'essentially they are considered in relation to the contribution they make to the understanding of the texts in their present, final form' (Rendtorff 2005:1-2). The term 'canonical' is explained as taking the Hebrew Bible in the final shape seriously as the founding document of the Jewish and Christian faith communities (Rendtorf 2005:2). Rendtorff's Old Testament theology is then presented in three parts. Part I deals with the biblical texts themselves following the sequence of the Hebrew Bible. The influence of von Rad is clear - like von Rad, this part is also a kind of 'retelling' von Rad insisted on. Part II extracts themes emanated from the texts dealt with in Part I. Part II then forms the systematic part of his presentation of the theology of the Old Testament dealing with themes like creation, covenant, the fathers of Israel, land, Torah, cult and so on. Part III is called 'The Hermeneutics of an Old Testament Theology' and deals with methodological consideration concerning the question of a canonical approach in more detail and the complicated issue of a Jewish and Christian Theology of the Hebrew Bible/Old Testament.

\section{Fischer}

Georg Fischer's 'Theologien des Alten Testaments' is interesting in that the title also has theology in its plural form of 'theologies' like the approach of Gerstenberger. What Fischer does in presenting his version of the 'theologies' of the Old Testament is to follow a book-by-book approach - reminiscent of the approach followed by House (1998) - where the 'Eigenheiten und Schwerpunkte' of the different books are highlighted (Fischer 2012:16). Different chapters are then devoted to the Torah, the former prophets, the latter prophets, the historical books (including the books regarded as canonical according to the Roman Catholic tradition) and finally the writings (once again including the books regarded as canonical according to the Roman Catholic tradition). The last part of the book is an overall perspective on who YHWH is according to the Old Testament. The book concludes with a short chapter on the relationship between the different theologies of the Old Testament and the New Testament.

\section{Jeremias}

Jeremias presents his version of the theology of the Old Testament making use of an insight from the French philosopher Paul Riccoeur. According to Jeremias (2015:6), Riccoeur distinguished five major literary genres (Grossgattungen) in the Old Testament: narratives, prophetic texts, legal texts, hymns and wisdom texts. These literary genres are called 'thought patterns' (Denkformen) by Jeremias and the identification of the basic thought patterns to be detected in the Old Testament then forms the basis from which he wrote his Old Testament theology. An Old Testament theology ought to be carried by the different thought patterns (Jeremias 2015:6). According to Jeremias, there are five central thought patterns in the Old Testament: the psalms, wisdom, legal texts, traditions about the origin of the people of God and prophecy. Jeremias's approach is certainly innovative but may also be seen as a kind of refinement of the approach of von Rad.

\section{Koorevaar and Paul}

The book published by Koorevaar and Paul (2013) is worth mentioning because it represents the first Old Testament Theology from Dutch soil since the publication of Vriezen's influential theology of the Old Testament way back in 1949. It is also unique in the sense that it is an Old Testament theology but written by different authors. The methodological approach followed represents a combination of a literary, historical, structural and canonical approach before theological conclusions are drawn. In the thematic-theological part, attention is paid to creation, Torah, sin, the promise of the seed of the woman (Gn 3:14-15) and the calling of Abraham, worship in Israel and land. Each theme is treated with attention to the different parts of the canon.

\section{Routledge}

The Old Testament theology presented by Routledge is guided by four interpretative principles: the exegesis of the text, discerning the underlying theological principles, translating those theological principles to the current context and fourthly to work out these principles in practice (Routledge 2008:78-79). The focus of his Old Testament theology is obviously on the second point of departure discerning underlying theological principles as the result of the exegesis of texts. The theological principles according to Routledge is then creation, election and covenant, God and his people, the future and finally, God and the gods. Routledge is sceptic of postmodern approaches like that of Brueggemann and Gerstenberger, and lays a major emphasis on the authority of the Bible.

\section{Waltke}

Waltke (2007) published a massive Old Testament theology comprising 969 pages excluding another 70 pages of cited 
works and indexes. The content of the book is arranged mainly around the theme of 'gift' as theological themes in the Old Testament. The approach followed is first of all exegetical, 'which traditionally means interpreting their [the text's] words in the languages that reflect their historical horizons' (Waltke 2007:9). The approach is secondly canonical because:

... the Bible is merely a collection of sixty-six books of various authors, it is one book, a canon inspired by one God, symbolized by the covers that bind them together as 'The Holy Bible'. (Waltke 2007:10)

Finally, all of this is then systemised in 29 'gifts'. The book is therefore divided into three parts: an introduction followed by a primary history and thirdly the other writings. The 'primary history' consists of the Decateuch (i.e. the Pentateuch, Deuteronomistic history as well as EzraNehemiah). The rest of the Old Testament is covered in the third part called the 'other writings' and consists of the prophetic literature, psalms and wisdom literature.

\section{Conclusion}

What conclusions may be drawn from this brief and superficial overview of developments in Old Testament theology? The conclusions arrived can be summarised in seven brief statements:

- In spite of death sentences pronounced upon the theology of the Old Testament, Old Testament theologies keep on appearing. Childs (1985:12) made the statement that Old Testament theology is a continuing enterprise in which each new generation must engage. The statement of Childs made in 1985 proved to be true. Since 1985, countless new attempts at writing an Old Testament theology were published in Europe, the United States and the United Kingdom. In a recent book, Hagelia (2012) makes the statement that:

... the writing of Old Testament Theology will prevail and has a future for the simple reason that the Old Testament texts are and will be forever among us with their religious and theological content. (p. 169)

- It is important to note that the intellectual and philosophical climate played an important role in the study of Old Testament theology. Brueggemann (1997) states in this regard:

It is of great importance for a student of Old Testament theology to notice that in every period of the discipline, the questions, methods and possibilities in which study is cast arise from the sociointellectual climate in which the work must be done. (p. 11)

- Modernist and postmodern approaches to Old Testament theology will coexist. Exploring recent developments showed that the more postmodern approaches of Brueggemann and Gerstenberger did not replace modernist approaches such as the ones by Rendtorff, Jeremias, Fischer, Routledge and Waltke, for instance. A rich diversity of approaches is the main characteristic in recent publications of books on Old Testament theology. In this regard, the field of Old Testament theology is no different from the rest of the different study fields in Old Testament. The present state of Old Testament can be seen as a kaleidoscope of approaches, methodologies and hermeneutical interests, and this is the way it will be for the foreseeable future.

- Whereas Old Testament theology was dominated by German scholarship in the past (Eichrodt and von Rad), Old Testament scholars from the US have made important contributions in the recent past (Childs and Brueggemann). While it was German scholars who were responsible for the major methodological innovations during the 20th century in Old Testament theology, it is an American scholar (Brueggemann) who introduced a fresh approach to Old Testament theology in the initial years of the 21st century.

- Women made a huge and important contribution to the understanding of the Old Testament in recent decades in all fields of the study of the Old Testament, yet an Old Testament theology written by a woman has not been published up till now.

- Africa has not yet produced a theology of the Old Testament. This is a challenge to Old Testament scholarship in Africa. Although the study of the Old Testament is a vibrant part of the study of theology in general, Africa has not yet produced an Old Testament theology originating from African soil.

- Old Testament theology is important in the wider theological discourses that are taking place. Multidisciplinary, interdisciplinary and trans-disciplinary studies in theology at large and even beyond the borders of theology are on the increase and the voice of the Old Testament may not be silenced in these approaches.

\section{Acknowledgements Competing interests}

The author declares that he has no financial or personal relationships which may have inappropriately influenced him in writing this article.

\section{References}

Albertz, R., 1994, A history of Israelite Religion in die Old Testament period, SCM, London.

Anderson, B.C., 1999, Contours of Old Testament theology, Fortress, Minneapolis, MN.

Barr, J., 1999, The concept of biblical theology: An Old Testament perspective, Fortress, Minneapolis, MN.

Brueggemann, W., 1997, Theology of the Old Testament. Testimony, Dispute, Advocacy, Fortress Press, Minneapolis, MN.

Childs, B.S., 1985, Old Testament theology in a canonical context, SCM, London. Childs, B.S., 1992, Biblical theology of the Old and New Testaments, SCM, London. Denton, R.C., 1963, Preface to Old Testament theology, Seabury, New York.

Dumbrell, W.J., 2002, The faith of Israel: A theological survey of the Old Testament, Baker, Grand Rapids, MI.

Eichrodt, W., 1975, Theology of the Old Testament, vol. I, SCM, London.

Fischer, G., 2012, Theologien des Alten Testaments, Verlag Katholisches Bibelwerk, Stuttgart.

Frör, K., 1968, Wege zur Schriftauslegung. Biblische Hermeneutik für Unterricht und Predigt, Patmos verlag, Düsseldorff.

Gerstenberger, E.S., 2002, Theologies of the Old Testament, T \& T Clark, London.

Goldingay, J., 2003, Old Testament Theology Vol 1: Israel's Gospel, Inter-Varsity Press, Downers Grove, IL. 
Hagelia, H., 2012, Three Old Testament theologies for today, Sheffield Phoenix Press, Sheffield. (Hebrew Bible Monographs 44).

Hasel, G.F., 1991, Old Testament theology: Basic issues in the current debate, Revised and expanded third edition, Eerdmans, MI.

Hayes, J.H. \& Prussner, F.C., 1985, Old Testament theology: Its history and development John Knox, Atlanta, GA

Hogenhaven, J., 1988, Problems and prospects of Old Testament Theology, JSOT Press, Sheffield.

House, P.R., 1998, Old Testament theology, InterVarsity Press, Downers Grove, IL.

Jeremias, J., 2015, Theologie des Alten Testaments, Vandenhoeck \& Ruprecht, Göttingen. (Grundrisse zum Alten Testament 6).

Koorevaar, H. \& Paul, M-J. (eds), 2013, Theologie van het Oude Testament. De blijvende boodschap van de Hebreeuwse Bijbel, Uitgeverij Boekencentrum, Zoetermeer.

Merrill, E.H., 2006, Everlasting dominion: A theology of the Old Testament, Broadman \& Holman, Nashville, TN

Perdue, L.G., 1994, The Collapse of history: Reconstructing old Testament Theology, Fortress, Minneapolis, MN.

Perdue, L.G., 2005, Reconstructing Old Testament theology: After the collapse of history, Fortress, Minneapolis, MN
Preuss, H.D., 1995, Old Testament theology, vol. I, Westminster John Knox Press, Louisville, TN.

Rendtorff, R., 2005, The Canonical Hebrew Bible. A theology of the Old Testament, Deo Publishing, Leiden.

Reventlow, H.G., 1984, The authority of the Bible and the Rise of the modern world SCM, London.

Reventlow, H.G., 1985, Problems of Old Testament Theology in the Twentieth Century. SCM, London

Routledge, H., 2008, Old Testament theology - A thematic approach, Apollos InterVarsity Press, Nottingham.

Sandys-Wunch, J. \& Eldredge, L., 1980, 'J P Gabler and the distinction between biblical and dogmatic theology: Translation, commentary and discussion of his originality', Scottish Journal of Theology 33,133-158. https://doi.org/10.1017/\$0036930 600047311

Von Rad, G., 1975, Old Testament theology, vol. I, SCM, London.

Waltke, B.K., 2007, An Old Testament Theology - An exegetical, canonical and thematic approach, Zondervan, Grand Rapids, MI.

Whybray, R.N., 1987, 'Old Testament theology - A non-existent beast?', in B.P. Thompson (ed.), Scripture: Meaning and method: Essays presented to A T Hanson for his seventieth birthday, pp. 168-180, Hull University Press, Hull. 